\title{
Do Instruction Skills Impress Employers?
}

\section{Chris Avery and Kevin Ketchner}

\begin{abstract}
Several members of the Education for Bibliographic Instruction Committee (ACRL Instruction Section) conducted a pilot project to investigate the perceived importance of library instruction skills to employers, and whether instruction experience or coursework is important in getting a job for which library instruction is a stated responsibility. Results of a telephone survey indicate that library instruction is viewed as an important service within academic libraries and that employers do consider skills or experience in the area of library instruction in the hiring process.
\end{abstract}

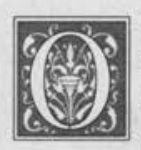

ver the years, a great deal has been written about the importance of library instruction within the academic library setting. Equally well documented is the perception that current training for library instruction is often insufficient and that there is a need for library school curricula to prepare librarians for library instruction duties. However, to date, library schools have demonstrated a reluctance to incorporate education for library instruction into their curricula, although there are some exceptions to this general trend (for example, at the State University of New York at Albany and at the University of California-Los Angeles). ${ }^{1}$ This reluctance is somewhat puzzling as almost all public service nonadministrative jobs in academic libraries (and a healthy percentage of technical services positions) include library instruction as a responsibility.
This apparent impasse attracted the attention of the Education for Bibliographic Instruction (EBI) Committee within the Instruction Section (IS, formerly the Bibliographic Instruction Section) of ACRL. The charge of this committee is in part to "explore, encourage, and foster the development and expansion of the study of bibliographic instruction in library schools." In thinking about ways to encourage the teaching of library instruction skills in library schools, committee members realized that investigating attitudes of employers toward library instruction might yield data lending further support to the idea of formal education in library instruction for library school students. Committee members hypothesized that employers would place some value on instruction skills given the widespread inclusion of instruction in job descriptions, and became interested in examining the role that library

Chris Avery is Social Sciences Librarian, Pattee Library, The Pennsylvania State University; e-mail: cca@psulias.psu.edu. Kevin Ketchner is Instruction Librarian, Cline Library, Northern Arizona University; e-mail: ketchner@nau.edu. This paper was sponsored by the Instruction Section of ACRL. 
instruction skills play in hiring decisions and whether such skills confer any competitive advantage. Committee members designed a pilot project in the form of a telephone survey to explore such issues.

\section{Review of the Literature}

In a search for relevant literature on the relationship between library instruction skills and the job market for librarians (as well as any mention of library school curricula as they relate to "employability"), it quickly becomes apparent that little is available. One of the few exceptions is an article by Charles Curran in which he discusses several topics related to teaching reference work. ${ }^{2}$ Curran urges library schools to consider the marketplace and what it requires. He notes that almost all new hires in public service positions will have instruction responsibilities and that library schools owe it to potential employers to provide candidates with suitable skills. Others, such as Lizabeth Wilson, have generally concentrated on discussions of needed proficiency in instruction and have made attempts to combine theory and practice in advocating the

\section{More than half of the respondents indicated that bibliographic instruction skills played a fairly important role in the hiring decision (53\% assigned a 4 or a 5 ).}

need for development of future library instruction education programs. ${ }^{3}$

The issue of encouraging incorporation of a course in library instruction into the library school curriculum is somewhat sensitive. There are two valid sides to the debate over whether such a course deserves to be included in the curriculum. The catalyst for recent debate is a 1990 survey conducted by Diana Shonrock and Craig Mulder. A sample of IS members evaluated the importance of eighty-four library instruction skills in a variety of categories. Members identified twentyfive skills that a librarian involved with library instruction should possess. For thirteen of these twenty-five skills, members had a preference for acquiring them through library school programs as opposed to acquiring them through other avenues. $^{4}$

Herbert S. White responded to early reports pertaining to the Shonrock--Mulder survey in an opinion piece. ${ }^{5}$ He summarizes the arguments on the other side of this coin (arguing against inclusion of library instruction in the curriculum) and addresses employment considerations as well. White contends that:

[S]ome of these sought-after attributes do not in any way describe librarianship as a discipline but only identify personality traits that the respondents found important for bibliographic-instruction librarians. ... The solution for employers in seeking to emphasize these skills seems simple. Employers should concentrate in their search on the kinds of people they are looking for. If they encounter candidates that do not meet these criteria, they should not hire them. ${ }^{6}$

White goes on to discuss the opinion voiced by many librarians that specific skills necessary in their professional lives were not taught in library school programs. He contends that complaints have more to do with lack of training for a specific job than with deficiencies in professional education. He concludes that, "At present we have no assurance that the hiring of prospective bibliographic instruction librarians will be predicated on the completion of the appropriate bibliographic instruction courses."7

Additional literature includes several studies written primarily by librarians who are involved firsthand with library instruction. The general theme seems to be that library instruction is being ne- 
glected in today's library school curricula. An example is Scott Mandernack's article, which discusses a survey of academic librarians. The survey examined the actual and preferred methods by which librarians acquire knowledge relevant to library instruction. ${ }^{8}$ Mandernack concludes that current training in library instruction is often insufficient and that organized continuing education courses are needed.

Also relevant is Robert Brundin's exploration of the reasons for the lack of attention in library school curricula to education for library instruction. ${ }^{9}$ Developments in education for library instruction and possible solutions to problem areas are highlighted in Brundin's article. Conversely, library instruction has made occasional inroads into the library school curriculum over the years. Mary Ellen Larson and Ellen Meltzer reported the results of a three-year study which collected the syllabi of library school courses that mentioned library instruction (19831986). They then analyzed the syllabi for the purpose of identifying trends in library instruction in the library school curriculum. ${ }^{10}$

Thus, the literature search shed some light on ways in which practicing librarians feel they could best be prepared to do library instruction, as well as on reasons why library instruction is usually not formally taught in library schools. The issue of the importance of library instruction skills in the marketplace and perceptions of employers related to library instruction skills appears to be uncharted territory. These results from the literature review led members of the EBI committee to the conclusion that a survey of employers would probably generate some interesting insights.

\section{Methodology}

The subcommittee decided that interviewing employers with fairly recent experience (within the past six months) in hiring a librarian would be the best means of answering questions about the impor- tance of instruction skills. To that end, the subcommittee developed a short questionnaire to be administered over the telephone which explored some aspects of the relationship between library instruction skills, the qualifications of newly hired librarians, and the hiring process. Subcommittee members pretested the questionnaire and refined it prior to conducting the interviews.

As a service to its members, ALA maintains a placement service during its Annual and Midwinter Conferences. Committee members examined job announcements and noted that there was a substantial amount of variation in types of libraries advertising positions. Members also were unable to discern a geographic bias

\section{The issue of the importance of library instruction skills in the marketplace and perceptions of employers related to library instruc- tion skills appears to be uncharted territory.}

to the announcements. Thus, they decided that for the purposes of this preliminary inquiry into employer attitudes toward library instruction, the job postings available at the placement center would represent a reasonable cross section of jobs available in academic libraries nationally and would provide a valid means of acquiring a sample of employers to interview. The EBI subcommittee examined job postings at the 1993 and 1994 ALA Midwinter Meetings from academic and special research libraries in which library instruction was stated as one of the job duties. Positions in which involvement in library instruction was limited to supervision or administrative responsibility were excluded. The job postings collected were primarily announcements for reference librarian positions, but there were a few for technical service positions that included a library instruction component. 


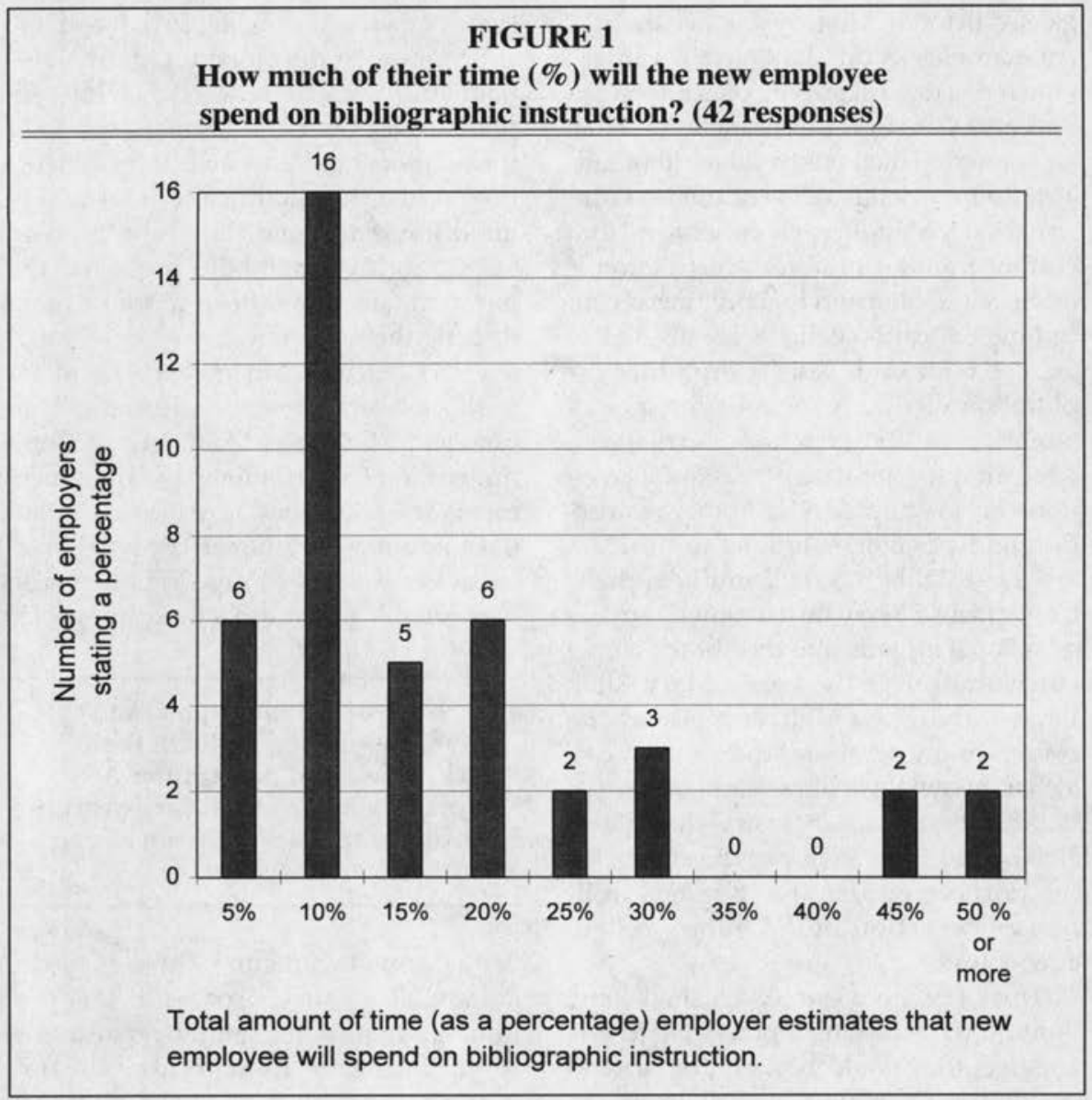

Through a process of trial and error (i.e., making calls and numerous followup calls), the subcommittee determined that it took a minimum of three to four months for job vacancies posted at Midwinter to be filled. Calls to employers in 1993 and 1994 yielded a total of forty-two complete questionnaires. As was the case in 1993, many of the calls made to employers listed on 1994 job postings did not result in an interview because the position advertised had not yet been filled. All of the employers contacted agreed to participate in an interview. In all cases, the interviewer asked to speak to the person with supervisory responsibility for the position advertised. At the end of the second round of interviews, the subcom- mittee decided that further interviews probably would not reveal much in the way of new information; a certain consistency in questionnaire responses had become apparent.

\section{Findings}

As indicated earlier, all of the interviews were conducted with employers who had actually filled a position involving library instruction within the previous six months. However, in half of the cases, the person hired had not actually started working. The sample consisted of a good mix of academic libraries, from large research libraries to small college libraries.

The subcommittee asked employers to estimate the amount of time the new em- 


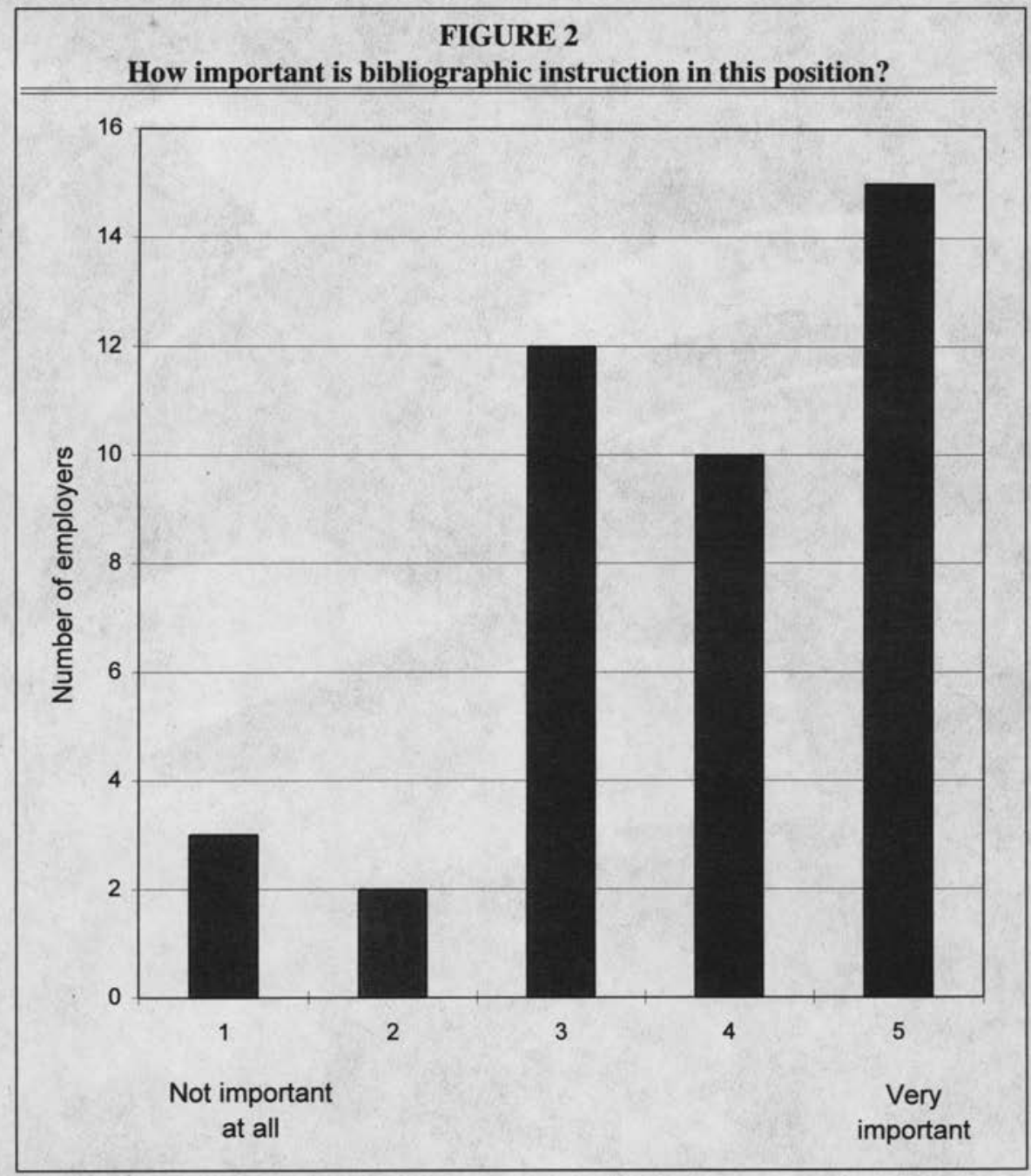

ployee would spend on activities related to library instruction. At the start of the interview, callers defined bibliographic instruction as "scheduled instruction or education done on an individual or group basis. Instruction done only at the reference desk is not considered to be bibliographic instruction in the context of this project." The percentage of time spent on library instruction ranged from a low of five percent to a high of 50 percent, with 10 percent being the most frequent response (see figure 1).

Employers were then asked to rank on a scale from 1 (low) to 5 (high) the importance of bibliographic instruction in the position being discussed. Only five employers assigned a ranking of 1 or 2 . Most employers indicated that bibliographic instruction was fairly important (about $60 \%$ assigned a ranking of 4 or 5 ). (See figure 2.)

Employers also were asked to rank (using the same scale) the importance of bibliographic instruction in their library. Results indicate that instruction matters a great deal in libraries. All employers (with the exception of one) gave a rank- 


\section{Set your information}
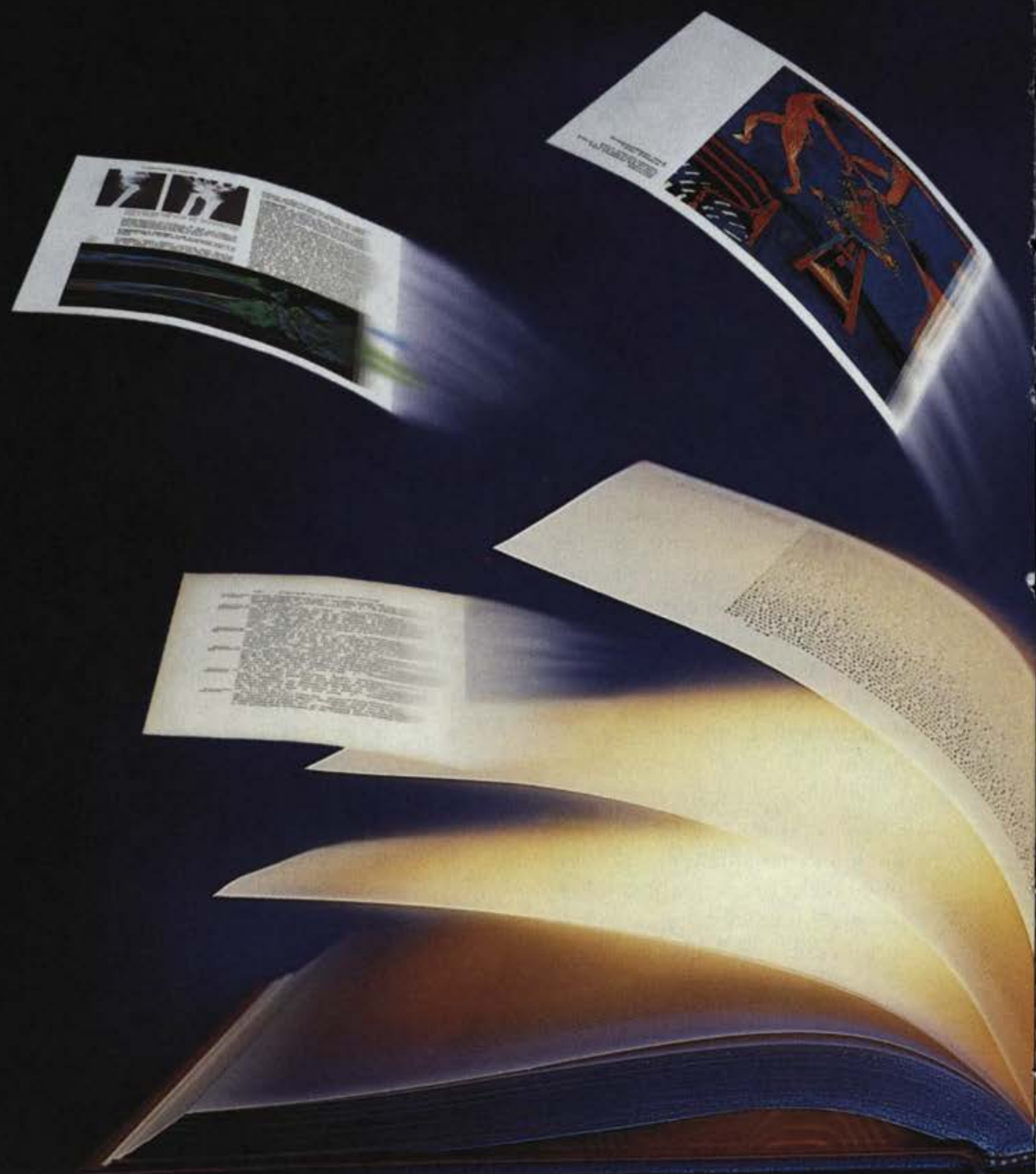

Scan any bound document face up and damage-free in seconds.
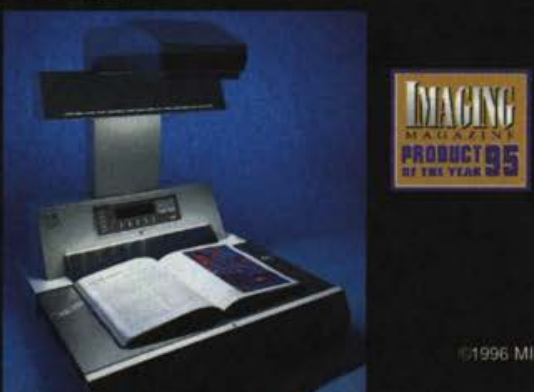

\section{Introducing Minolta}

Scan, copy and send information from any bound document interoffice, interlibrary or internationally. Bound up by bound documents? Digitize and distribute information worldwide with one of the EPIC 3000 systems. Scan fragile books, documents and even 3-D objects face up and damage-free. Then archive or distribute the information however you please. EPIC 3000 for Windows ${ }^{\text {Th }}$ 


\section{freel}

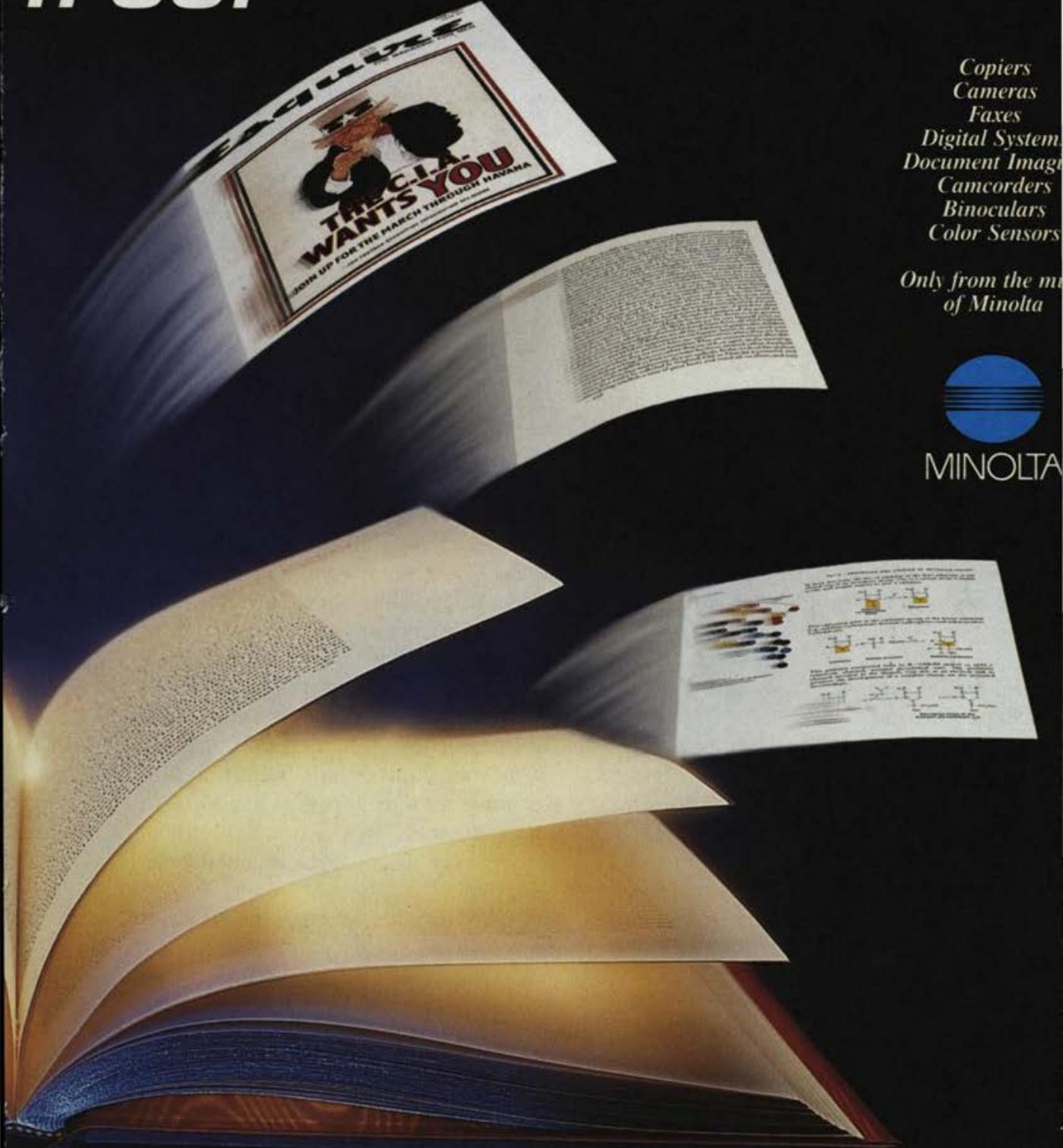

\section{EPIC 3000}

lets you print or fax. E-mail information.

Store on any form of media. Or put it on the Internet. The patron-friendly EPIC 3000 with touch screen comes ready for paper or electronic output.

Don't get caught in a bound document bind.

For more information call 1-800-9-MINOLTA
Simple touch screen monitor lets patrons print or store to disk. 


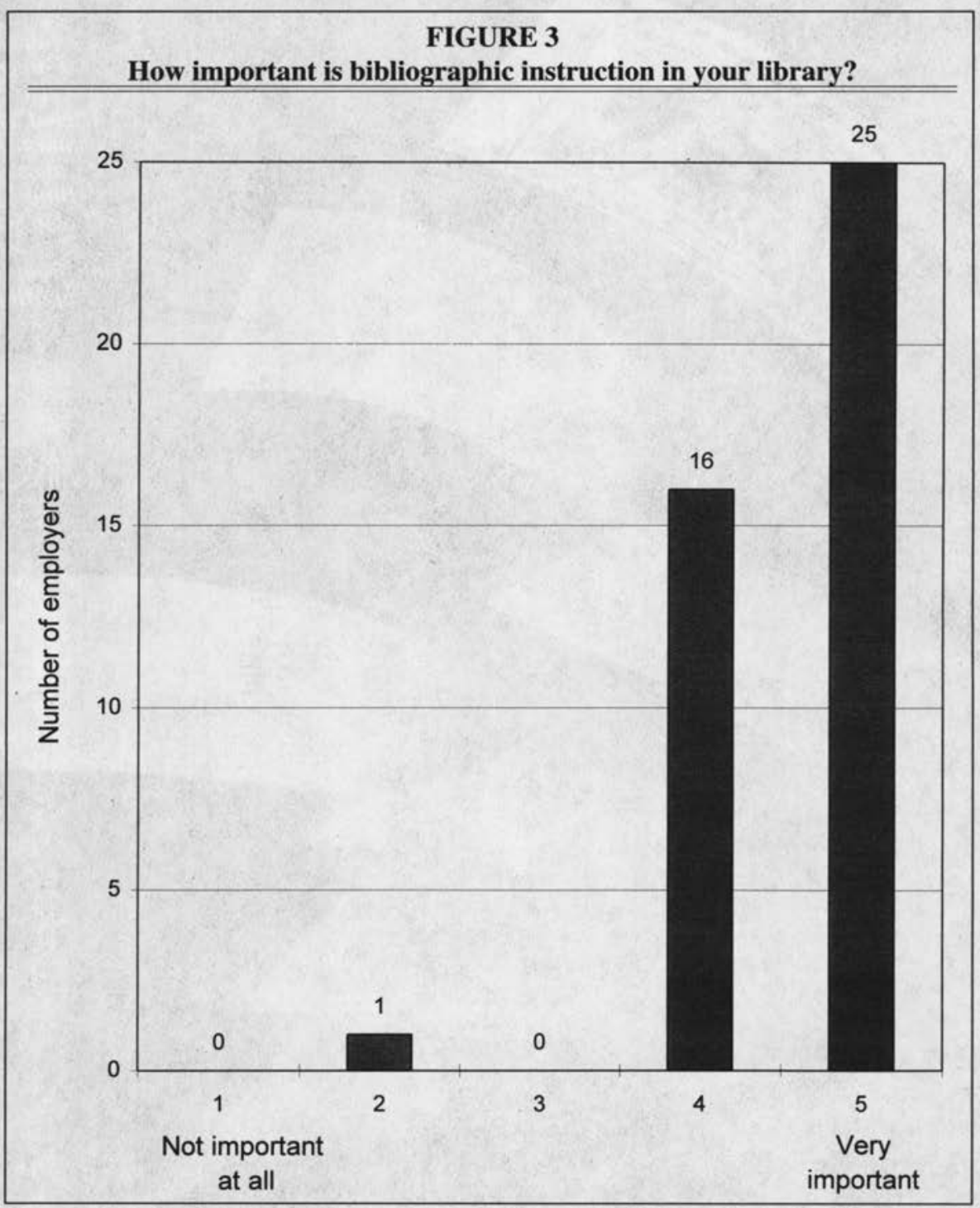

ing of 4 or 5 . The most frequent response was to assign a ranking of 5 (very impor$\tan$ t). (See figure 3.)

When subcommittee members asked employers about the types of activities the librarian just hired was or would be involved in, all indicated that he or she would be delivering one-time courses and workshops. Almost all said that the librarian would be developing instruction and courses, and about ten employers indicated that he or she would be coordinating a library instruction program. Relatively few (eight) said that the newly hired librarian would be delivering an extended course and even fewer (five) said that he or she would be supervising other instructors.

The employers also were asked if they have an in-house training program for 


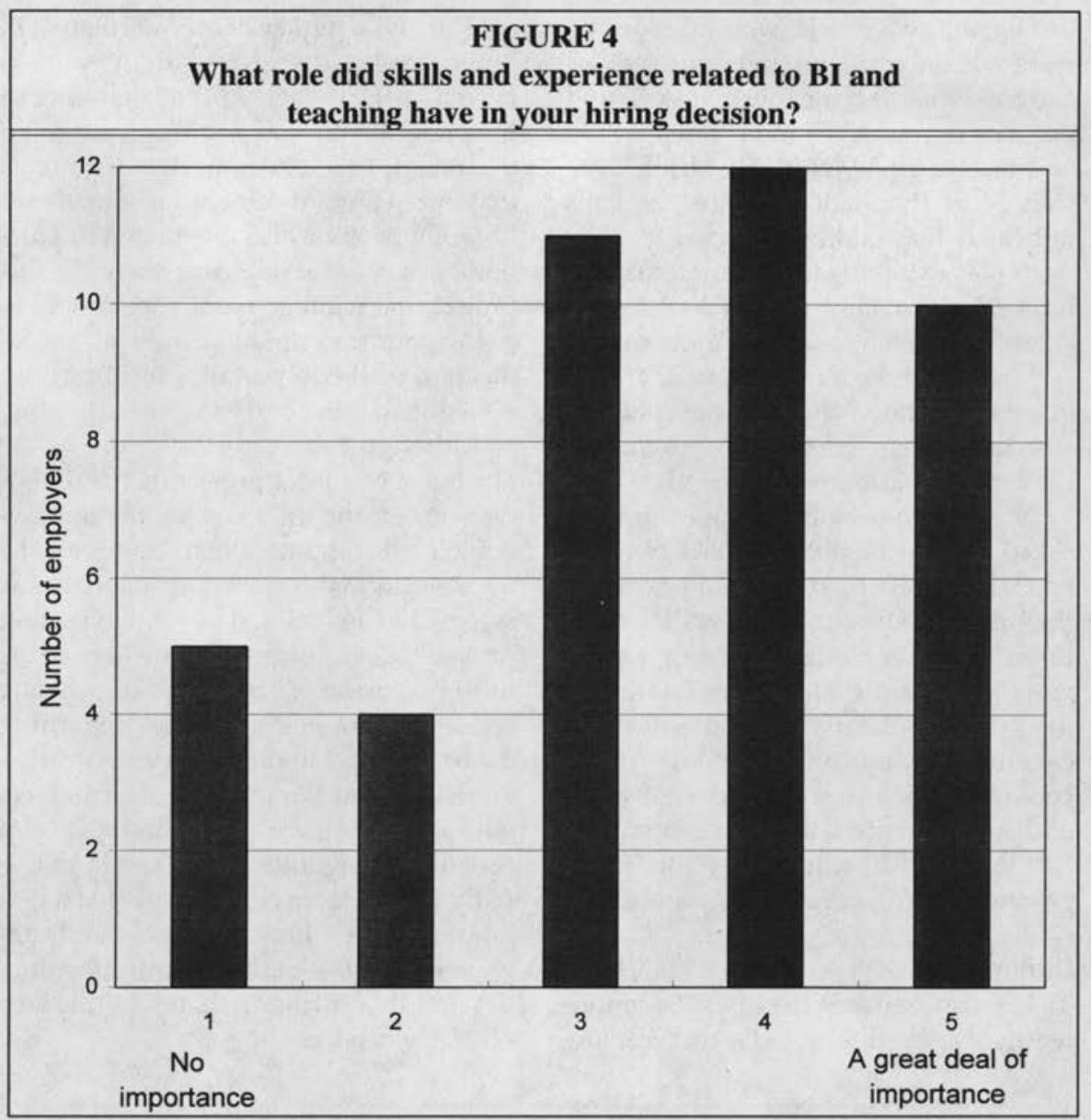

librarians involved in library instruction. About a third indicated they did and about two-thirds said they did not. When subcommittee members asked employers how a new librarian learns to do instruction, a variety of answers was given, including on-the-job training, observation of others followed by assisting more experienced colleagues, teamwork, workshops, and trial and error. When asked what they thought was the best way to prepare someone to do instruction, about half the employers mentioned observation and working with others and almost half mentioned using workshops. Fifteen employers (about a third) thought that library instruction skills should be taught in library schools, and six thought their library should develop a formal training program.

In about 75 percent of the positions the subcommittee inquired about, library instruction skills were a preferred qualification in the job posting and not a requirement. Most of the employers ( $86 \%$ ) indicated that they asked candidates if they had previous teaching experience, but only a third said they asked candidates if they had taken any courses in library instruction or education. When employers were questioned about the actual interview process, well over half said that candidates were required to make some sort of presentation on a topic. 
The supervisors who were interviewed were asked to rank (on the same scale of 1 to 5 used earlier) the role that skills and experience related to library instruction and teaching played in the hiring decision. More than half of the respondents indicated that bibliographic instruction skills played a fairly important role in the hiring decision (53\% assigned a 4 or a 5 ). About 26 percent assigned a ranking of 3,9 percent gave a ranking of 2 , and 12 percent indicated that bibliographic instruction skills were of no importance in the hiring decision (see figure 4).

As a final question, the subcommittee asked supervisors to think back over the entire interviewing process and say what the most important factor was for them in hiring the candidate. Although some employers said that the candidate had made an excellent presentation or had excellent communication skills, most couldn't pinpoint a single factor. Answers such as "reference skills and personality," "attitude and qualifications," or "background and subject expertise" were given.

\section{Summary}

The general sense of the EBI subcommittee involved in this project is that employ- ers showed a higher degree of interest in bibliographic instruction than was expected at the outset. At the beginning of the project, while job postings were being examined, the subcommittee did notice that every announcement for a reference librarian position also mentioned instruction. However, the degree of interest in this project, the willingness of supervisors to participate, and the uniformly strong indication of the importance of library instruction within libraries were surprising.

Although this study has more of the attributes of a pilot project than a definitive survey, the interviews with employers left subcommittee members with the impression that instruction experience is recognized and valued by employers and probably does figure to some extent in the hiring decision. There was not a strong consensus among employers regarding the best way for librarians to learn instruction skills, but the number of employers who actually mentioned library school courses was significant. The results of this fairly informal survey indicate that a dialogue between library schools and employers on this topic holds some possibilities and that further research in this area is clearly needed.

\section{Notes}

1. Shirley Cody, Esther Grassian, and Trudi Jacobson, "Sample BI Course Syllabus," available from Project LOEX at Eastern Michigan University Library, Learning Resources and Technology, 48197. In the process of creating a sample course syllabus in 1993, ten library schools in the United States and Canada with full courses in library instruction were identified.

2. Charles Curran, "Teaching about Reference Work," Reference Librarian 25-26 (1989): 465-81.

3. Lizabeth A. Wilson, "Education for Bibliographic Instruction: Combining Practice and Theory," Journal of Education for Library and Information Science 28 (summer 1987): 17-25.

4. Diana Shonrock and Craig Mulder, "Instruction Librarians: Acquiring the Proficiencies Critical to Their Work," College \& Research Libraries 54 (Mar. 1993): 137-49.

5. Herbert S. White, "Bibliographic Instruction and the Library School Curriculum," Journal of Education for Library and Information Science 32 (fall/winter 1991): 194-202.

6. Ibid., 195.

7. Ibid., 202.

8. Scott B. Mandernack, "An Assessment of Education and Training Needs for Bibliographic Instruction Librarians," Journal of Education for Library and Information Science 30 (winter 1990): 193-205.

9. Robert E. Brundin, "Education for Instructional Librarians: Development and Overview," Journal of Education for Library and Information Science 25 (winter 1985): 177-89.

10. Mary Ellen Larson and Ellen Meltzer, "Education for Bibliographic Instruction," Journal of Education for Library and Information Science 28 (summer 1987): 9-16. 